\author{
ks. Marcin Dera ${ }^{1}$ \\ 0000-0002-5710-6047 \\ Uniwersytet Papieski Jana Pawła II w Krakowie
}

\title{
Działanie Ducha Świętego w życiu chrześcijanina na podstawie wybranych homilii św. Jana Chryzostoma
}

Święty Jan Chryzostom urodzony pomiędzy 344 i 350 rokiem w Antiochii ${ }^{2}$ należy do grona najwybitniejszych kaznodziejów starożytności chrześcijańskiej. Wyróżniał się swoistym stylem, który nie koncentrował się na teologicznych subtelnościach, ale na poszukiwaniu rozwiązań problemów trapiących ówczesną społeczność chrześcijańską. W swoich homiliach nie skupiał się na tłumaczeniu formuł teologicznych dotyczących Boga Ojca, Syna Bożego czy Ducha Świętego, lecz na konieczności współpracy wierzącego z łaską Bożą, którą obdarowuje Duch święty. Niewątpliwie na takie podejście miały wpływ okoliczności, z którymi Złotousty musiał się zmierzyć w swojej młodości.

1 Ks. Marcin Dera - mgr. lic.; urodzony w 1978 roku w Lublinie. Od 2003 roku prezbiter archidiecezji gdańskiej. W 2003 roku ukończył Uniwersytet Kardynała Stefana Wyszyńskiego w Warszawie, uzyskując tytuł magistra teologii. W 2009 roku ukończył studia na Wydziale Teologii Uniwersytetu Warmińsko-Mazurskiego w Olsztynie, uzyskując tytuł licencjata teologii. E-mail: dera.marcin@gmail.com.

2 Badacze życia i działalności św. Jana Chryzostoma ustalili najbardziej prawdopodobną datę urodzin na 349 rok. Zob. J. N. D Kelly, Złote usta. Jan Chryzostom, Bydgoszcz 2001, s. 16. 
W związku z powyższym opracowanie rozpocznie się od ukazania krótkiego rysu biograficznego św. Jana Chryzostoma z zaznaczeniem problemów doktrynalnych dotyczących różnych odmian arianizmu, reakcji pogaństwa i Soboru w Nicei. Następnie zostaną przedstawione jego homilie doktrynalne wygłoszone przeciwko arianom i przy okazji Zielonych Świąt i Epifanii. Następnie ukazane zostanie nauczanie Złotoustego na temat Ducha Świętego w homiliach katechetycznych skierowanych do katechumenów antiocheńskich. W ostatniej części zostanie omówione nauczanie św. Jana Chryzostoma na temat Ducha Świętego w homiliach polemicznych skierowanych przeciwko judaizantom (judeochrześcijanom), Żydom i Hellenom (poganom). Należy zauważyć, że Złotousty nie zajmował się tematami stricte doktrynalnymi dotyczącymi Osoby Ducha Świętego.

\section{Konfrontacja św. Jana Chryzostoma ze sporami teologicznymi dotyczącymi Ducha Świętego}

Dorastanie i zdobywanie wykształcenia Jana Chryzostoma zbiegło się z przyswajaniem przez Kościół dekretów Soboru w Nicei. Młody Chryzostom był świadkiem polemik, a nawet kłótni doprowadzających do wygnania biskupów wiernych postanowieniom soborowym. W Antiochii większość urzędów obsadzili zwolennicy arianizmu. Święty Jan Chryzostom przystąpił do zwolenników Soboru Nicejskiego, co wpłynęło na jego karierę w Kościele antiocheńskim³ . Pod koniec swojej nauki, pobieranej od retora Libaniosa, porzucił propozycję świeckiej kariery na rzecz zajęcia się „prawdziwą filozofią”, czyli rozważaniem Pisma Świętego. W tym czasie dostał się pod wpływ prawowiernego biskupa Melecjusza. Z jego rąk przyjął sakrament chrztu św. i pozostał w służbie hierarchy. Dzielił z biskupem niedolę wygnania i zakazu wstępowania do Antiochii.

Pobierał nauki w szkole prawowiernych chrześcijan Diodora i Karteriusza. W czasie nauki poznał dosłowną metodę interpretacji Pisma

3 Szerzej na ten temat: Zob. J. N. D. Kelly, Złote usta. Jan Chryzostom, Bydgoszcz 2001, s. 22-23. 
Świętego, którą później stosował w swoich homiliach. Dowodem tego jest krótkie dziełko, które nie jest homilią, ale ukazuje stosunek Złotoustego do działania Ducha Świętego. Święty Jan Chryzostom w liście Do Teodora po jego upadku napisał, że Trzecia Osoba Trójcy Świętej działa w szczególny sposób w osobie mnicha. Duch Święty udziel mu potrzebnych łask i daje moc uwalniania od zła i cierpienia ${ }^{4}$.

W tym czasie prawowierny biskup Melecjusz rozpoznał w Złotoustym kandydata do stanu duchownego. Święty Jan uznał, że nie jest godny takiego zaszczytu i uciekł w okoliczne góry, by wieść życie pustelnika. Niestety w wyniku dekretu cesarza Walensa biskup musiał opuścić teren Antiochii i udać się na wygnanie do Armenii. W ten sposób młody Chryzostom uniknął posługi kapłańskiej na kilka następnych lat.

Czas pobytu w pustelni zaowocował w życiu św. Jana otwarciem się na działanie Ducha świętego. Poprzez modlitwę i rozmyślanie nauczył się na pamięć tekstów Starego i Nowego Testamentu. Po spędzeniu kilku lat w pustelni Chryzostom powraca do Antiochii z powodu pogorszenia stanu zdrowia. W tym czasie na mocy amnestii wraca do miasta biskup Melecjusz, który wyświęca Złotoustego na diakona ${ }^{5}$. Nie mogąc jeszcze głosić homilii poświęcił się posłudze przy biskupie oraz pisaniu krótkich dzieł o tematyce apologetycznej i moralnej. Ukazał w nich wyższość chrześcijaństwa nad pogaństwem oraz judaizmem, a także doniosłość dziewictwa i życia mniszego. Bronił idei życia mniszego przed wrogami ascetyzmu oraz krytykował wspólne zamieszkiwanie dziewic i mnichów - jako moralnie niebezpieczne. Wiele pomysłów, które przedstawił w ówczesnych pismach było niepraktycznych. Przykładem mógł być postulat posyłania dzieci na 10 lat do klasztoru w celu pobierania nauki i wzrastaniu w łasce. Tego typu zachęty można przenieść na karb młodego wieku i gorącego zapału graniczącego z naiwnością. Jego literacka płodność zwróciła uwagę nowego biskupa Flawiana, który został wybrany po śmierci Melecjusza. Hierarcha postanowił wyświecić Złotoustego na urząd prezbitera i powierzyć mu głoszenie homilii'

\footnotetext{
Zob. J. N. D. Kelly, Złote usta. Jan Chryzostom, dz. cyt., s. 32.

5 Por. J. N. D. Kelly, Złote usta. Jan Chryzostom, dz. cyt., s. 50-51.

6 Por. J. N. D. Kelly, Złote usta. Jan Chryzostom, dz. cyt., s. 65.
} 


\section{Homilie doktrynalne przeciwko arianom oraz z okazji Zielonych Świąt i Epifanii}

Młody prezbiter był odpowiedzialny za głoszenie homilii. Bardzo szybko zyskał sobie popularność i gromadził na celebracjach tłumy, które chciały słuchać Jego nauczania ${ }^{7}$. W swoich homiliach piętnował grzeszny styl życia wielu chrześcijan, ukazywał drogę nawrócenia i zachęcał do poprawy. Jego wypowiedzi były improwizowane i nacechowane różnymi wstawkami, w których np.: ganił słuchaczy, że przyszli posłuchać kazania, po którym opuszczają zgromadzenie i nie przyjmuja Chrystusa ${ }^{8}$.

Popularność homilii św. Jana Chryzostoma była spowodowana prostotą przekazu. Złotousty nie wygłaszał doktrynalnych przemówień. Jedynym odstępstwem od tej praktyki były homilie wygłoszone w Wielkim Poście 386 roku po Chrystusie. Po serii mów na temat Księgi Rodzaju zajął się zwalczaniem skrajnego odłamu arianizmu, który zdobywał sympatyków w Antiochii. W pięciu homiliach zwalczał poglądy Eunomiusza - twórcy skrajnego odłamu arianizmu. Szczególnie interesujące są dwie ostatnie homilie. Złotousty wyłożył w nich naukę na temat związku Boga Ojca z Synem i Duchem Świętym. Na podstawie Ewangelii według św. Jana i Pierwszego Listu do Koryntian wyjaśniał, że Syn Boży i Duch Święty są nie tylko pełnymi posiadaczami wiedzy Boga Ojca, ale także dzielą z nim boskość, oddzieleni od Niego jako Osoby oraz działają w człowieku9.

7 Por. J. N. D. Kelly, Złote usta. Jan Chryzostom, dz. cyt., s. 67.

8 Por. J. N. D. Kelly, Złote usta. Jan Chryzostom, dz. cyt.

9 Por. J. N. D. Kelly, Złote usta. Jan Chryzostom, dz. cyt., s. 72. Także: „«Spiritus est Deus» (Joan 4, 24) Hoccine dic mihi substantiam ejus declarat? Ecquis haec ferat, si vel tantillum ad Scripturae sacrae fores accesserit? Nam hac ratione Deus ignis quoque erit; quaemadmodum enim scriptum est: «Spiritus est Deus»; ita quoque scriptum est: «Deus noster ignis consumens est» (Hebr 12, 29); ac rursum «Fons aquae vivae» (Jerem 2, 13). Neque Spiritus fons et ignis tantum erit sed etiam animam, ventus, mens humana, et alia his longe absurdiora; non enim omnia recensere opus est, neque illorum insaniam imitari. Hoc enim nomen spiritus multa significat; animam nempe nostram ut ait Paulus, «Tradite hujusmodi hominem satanae, ut spiritus salvus sit» (1 Cor 5, 5); itemque ventum secundum prophetam, «Spiritu vehementi conteres eos» (Psal 47, 8); donum etiam spirituale sic vocatur: «Ipse enim spiritus testimonium reddit spiritui nostro (Rom 8, 16)", De incomp. 
Jan Chryzostom w niewielu homiliach wypowiada się wprost na temat działania Ducha Świętego w życiu chrześcijanina. Wyjątkiem od tego są wystąpienia Złotoustego w czasie uroczystości Zesłania Ducha Świętego w 386 roku i w święto Epifanii $387 \mathrm{roku}^{10}$. W homilii na zesłanie Ducha Świętego wyjaśniał uczniom, że wylanie Ducha na apostołów przemieniło ich w istoty anielskie i dało nadnaturalną siłę. Tłumaczył antiocheńczykom, że dar Trzeciej Osoby Trójcy Świętej dla grzesznego człowieka ma moc pojednać go $\mathrm{z}$ Bogiem ${ }^{11}$. W tym samym wystąpieniu wyjaśniał słuchaczom, że heretycy się mylą, umniejszając rolę Ducha Świętego. Według Złotoustego przeciwnicy wiary w boskość Trzeciej Osoby Trójcy Świętej urągają przywilejom, jakimi cieszą się chrześcijanie: przebaczenie grzechów, dostęp do Boga przez modlitwę oraz autorytetowi biskupa, który ma prowadzić liturgię w Duchu Boga ${ }^{12}$.

W dalszej części homilii św. Jan Chryzostom tłumaczył swoim słuchaczom powody niewystępowania tak spektakularnych cudów, jakie działy się w czasie zesłania Ducha Świętego. Złotousty stwierdził, że w czasach apostolskich ludzie wydobywali się z mroków pogaństwa i judaizmu i potrzebowali namacalnych dowodów działania Ducha. Dojrzały chrześcijanin powinien zrozumieć, że cuda i łaski postrzega się duchowo ${ }^{13}$. Święty Jan skończył swoją homilię, obrazując Ducha spalającego ludzkie grzechy, podobnie jak ogień pochłania ciernie, oraz dzień sądu, przed którym, chrześcijanin może stanąć z ufnością, jeśli zmazał swoje grzechy łaską Ducha Świętego ${ }^{14}$.

5. 5, ed. J. P. Migne, Paris 1857-1866, kol. 735-748 (Patrologiae cursus completus. Series Graeca [dalej: PG], 48).

10 De s. Pentecoste hom.; In diem natalem Dom. Nostrii Iesu Christii; De baptisamte Christi et de Epiphania (PG 50. 453-464; 49. 352-62; 363-372). Cyt. za: J. N. D. Kelly, Złote usta. Jan Chryzostom, dz. cyt., s. 77.

11 Por. De s. Pentecoste 1.2-3 (PG 50.456-457). Zob. także: J. N. D Kelly, Złote usta. Jan Chryzostom, dz. cyt., s. 77.

12 Por. De s. Pentecoste, 1.4 (PG 50. 458-9). Zob. J. N. D Kelly, Złote usta. Jan Chryzostom, dz. cyt., s. 77.

13 Por. De s. Pentecoste, 1.4 (PG 50. 458-9).

14 Por. De s. Pentecoste, 1.5 (PG 50. 460-1). Zob. także: J. N. D Kelly, Złote usta. Jan Chryzostom, dz. cyt., s. 78. 
W homilii wygłoszonej podczas święta Epifanii Złotousty ukazał, że prawdziwa natura Chrystusa została ukazana nie przy narodzeniu, ale przy chrzcie, kiedy Duch Święty zstąpił na Zbawiciela ${ }^{15}$.

Święty Jan Chryzostom ukazywał w obu homiliach Ducha Świętego jako Trzecią Osobę Trójcy Przenajświętszej, równego Bogu Ojcu i Synowi w boskiej naturze, godnego tej samej czci. Według Złotoustego Duch działa w człowieku, by zbliżać go do Boga Ojca i Jezusa Chrystusa.

\section{Rola Ducha Świętego na podstawie homilii katechetycznych św. Jana Chryzostoma}

Do wielu zadań, którymi był obarczony św. Jan Chryzostom należało także przygotowanie katechumenów do chrztu świętego. Rozpoczęcie przygotowania dokonywało się przez egzamin z dotychczasowego życia. Kandydat musiał posiadać opinię od chrześcijanina (ojca chrzestnego), by rozpocząć katechumenat ${ }^{16}$. Bezpośrednie przygotowanie do chrztu odbywało się przez dwa lata. Katechumen miał prowadzić wzorowe życie, przestrzegać postów i słuchać homilii katechetycznych ${ }^{17}$.

Katechezy chrzcielne św. Jana Chryzostoma zawierają w sobie elementy doktrynalne i moralne. Mimo doktrynalnej specyfiki nauk przygotowujących do sakramentów, Złotousty w swoich wystąpieniach w większym stopniu kładzie nacisk na elementy moralne, przestrzegając katechumenów przed złym przykładem grzesznych chrześcijan i heretyków. W Pierwszej katechezie przestrzega katechumenów przed zgubnymi skutkami arianizmu i sabelianizmu: „Gdyby was chcieli oszukać zwolennicy Ariusza, zatkajcie sobie uszy na ich słowa, śmiało im odpowiadając i wskazując, że Syn co do istoty jest podobny do Ojca, albowiem powiedział: «Jak Ojciec wskrzesza umarłych i życie im przywraca, tak i Syn daje życie, komu zechce». We wszystkim wskazuje, że Jego moc jest równa

15 Por. De baptismo Christi 2 (PG 49. 365-6). Por. także: J. N. D Kelly, Złote usta. Jan Chryzostom, dz. cyt., s. 78.

16 Por. M. Starowiejski, Antiocheńskie katechezy chrzcielne w IV wieku, w: J. Chryzostom, Katechezy chrzcielne, Lublin 1993, s. 14.

17 Por. J. Chryzostom, Katechezy chrzecielne, dz. cyt., s. 14. 
mocy Ojca. Gdyby zaś z drugiej strony zapragnął zepsuć zdrowe prawdy Sabeliusz przez to, że miesza Osoby, obwaruj, kochany, swe uszy, wiedząc, że jedna jest istota Ojca i Syna i Ducha Świętego, trzy natomiast Osoby"18.

W kolejnej katechezie objaśniał, że sakrament chrztu dokonywany jest mocą Ducha Świętego: „[Kapłan] prowadzi was do świętej wody, grzebiąc starego człowieka i wskrzeszając nowego, odnowionego na obraz Stwórcy. Dzieje się to w chwili, kiedy przez słowa kapłana i jego ręce zstępuje Duch Święty"19. Dalej przypomina naukę o jedności w istocie i majestacie Trójcy Świętej, która składa się z Trzech Osób Boskich ${ }^{20}$, natomiast w czwartej katechezie przypomniał neofitom, że mieszka w nich Trójca Święta ${ }^{21}$. Niewiele homilii chrzcielnych autorstwa św. Jana Chryzostoma dotrwało do naszych czasów ${ }^{22}$. Zaskakujące może wydawać się, jak mało miejsca poświęcił Złotousty na wykład dogmatów wiary. Może być to spowodowane okolicznościami wystąpień. Większość zachowanych homilii dotyczyła neofitów, których przestrzegał przed grzechami trapiącym ówczesną społeczność Antiochii. Można przypuszczać, że homilie doktrynalne znalazły się w zbiorze, który nie zachował się do naszych czasów.

\section{Nauczanie św. Jana Chryzostoma na temat Ducha Świętego w homiliach polemicznych skierowanych przeciwko judaizantom (judeochrześcijanom), Żydom i Hellenom (poganom)}

Szczególnym zbiorem homilii, w których św. Jan Chryzostom omawiał rolę i działanie Ducha Świętego w życiu człowieka są homilie i mowy przeciwko judaizantom, Hellenom i Żydom. Ukazywał w nich z jednej strony zdradę Boga, dokonaną przez wyznawców judaizmu, z drugiej przekleństwo potępienia, jakie sprowadzają na siebie poganie, którzy nie chcą nawrócić się do Boga.

\footnotetext{
J. Chryzostom, Katechezy chrzecielne, I, 22, dz. cyt., s. 30.

J. Chryzostom, Katechezy chrzecielne, II, 25, dz. cyt.,, s. 49.

Por. J. Chryzostom, Katechezy chrzecielne, II, 26-27, dz. cyt., s. 49-50.

Por. J. Chryzostom, Katechezy chrzecielne, IV, 4, dz. cyt., s. 64.

Por. M. Starowiejski, Antiocheńskie katechezy chrzcielne w IV wieku, dz. cyt., s. 8-9.
} 
Przykładem wystąpienia Złotoustego, ukazującego moc Ducha Świętego, której sprzeciwili się Żydzi, jest Szósta mowa przeciw judaizantom i Żydom. Kaznodzieja spierał się z diasporą żydowską na temat zburzenia Jerozolimy i wygnania Narodu Wybranego z Palestyny. Nie zgadzał się z twierdzeniami oponentów, że było to dzieło człowieka. Dla Złotoustego to wydarzenie było karą Bożą za nieposłuszeństwo Bogu i natchnieniom Ducha, który przemawiał przez proroków: „Gdyby wasza klęska była dziełem ludzi, to wasze nieszczęście powinno zakończyć się wraz z zajęciem [Jerozolimy], a razem z nim ciążąca na was pogarda. Przypuśćmy, że tak jak sądzicie, to ludzie zburzyli Miasto i zniszczyli ołtarz; czy także ludzie sprawili, że zamilkli wasi prorocy, czy ludzie pozbawili was łaski Ducha i wszelkich innych danych wam świętości?"23. Święty Jan Chryzostom przestawił argumenty, że utrata łaski Bożej dawanej przez Ducha $^{24}$ jest wynikiem zdrady Narodu Wybranego wobec Mesjasza - Syna Bożego ${ }^{25}$. Złotousty w bardzo mocnych słowach określił współczesnych mu Żydów i ich miejsca modlitwy: „Jeśli wtedy, kiedy arka z Cherubinami jeszcze istniała, kiedy Świątynia jeszcze była uświęcona łaską Ducha Świętego, (Bóg) powiedział: «Uczyniliście z niej jaskinię rozbójników», a także: $z$ domu [mego] targowisko, bo łamali Prawo i byli krwiożerczy, to jakimi dzisiaj słowy możemy nazwać ich synagogi? Kiedy opuściła ich łaska Ducha Świętego, kiedy nie korzystają już ze swoich przywilejów i zniesione zostały ofiary miłe Bogu, a oni mu oddają cześć tylko bluźnierczą" ${ }^{26}$. Receptą na odrzucenie przez Boga jest przyjęcie chrztu świętego: „Chcesz zobaczyć Świątynię - nie biegnij do synagogi, lecz sam się stań Świątynią. [...] Ozdabiaj ten dom, wypędź każdą złą myśl, aby stać się drogocennym członkiem Jezusa Chrystusa i świątynią Ducha; uczyń także innych takimi [świątyniami]"27. Jak wynika z powyższych

${ }^{23}$ J. Chryzostom, Mowy przeciw judaizantom i Żydom. Przeciwko Żydom i Hellenom, VI, 4, Kraków 2007, s. 179.

24 Który przemawiał przez proroków i uświęcał olej do namaszczenia kapłanów i królów. Zob. J. Chryzostom, Mowy przeciw judaizantom i Żydom. Przeciwko Żydom i Hellenom, VI, 4, Kraków 2007, s. 179..

25 Por. J. Chryzostom, Mowy przeciw judaizantom i Żydom, VI, 3, dz. cyt., s. 178.

26 J. Chryzostom, Mowy przeciw judaizantom i Żydom, VI, 7, dz. cyt., s. 188.

27 J. Chryzostom, Mowy przeciw judaizantom i Żydom, VI, 7, dz. cyt., s. 188. 
fragmentów według Złotoustego bycie członkiem Narodu Wybranego to nie kwestia narodzenia, ale wiary w Jezusa Chrystusa i współpracy z Duchem Świętym. Duch Święty dał moc apostołom, którzy skutecznie głosili Chrystusa narodom pogańskim ${ }^{28}$.

Św. Jan Chryzostom z troską pochylał się nad kondycją judaizantów. Dał temu wyraz w dziele - wcześniejszym od Mów przeciwko judaizantom iŻydom - Komentarzu do Listu św. Pawła do Galatów, w którym przypomina, że wiara umacniana jest mocą Ducha Świętego, a nie uczynkami Prawa ${ }^{29}$.

Nauczanie św. Jana Chryzostoma, dotyczące działania Ducha Świętego w życiu człowieka, koncentrowało się na okazjonalnych homiliach z racji uroczystości zesłania Ducha Świętego czy święta Epifanii oraz w wypowiedziach będących konfrontacją z herezjami obecnymi w Antiochii. Nieobecność tematu Ducha Świętego w homiliach do wiernych można tłumaczyć sposobem ich wygłaszania przez Złotoustego, który koncentrował się w wypowiedziach głównie na moralności antiocheńczyków, a w późniejszym okresie mieszkańców stolicy cesarstwa.

28 Por. J. Chryzostom, Mowy przeciw judaizantom i Żydom, VI, 7, dz. cyt., s. 242.

29 J. Chryzostom, Komentarz do Listu do Galatów, III, 1, Kraków 2008, s. 88. 


\section{Summary}

Działanie Ducha Świętego w życiu chrześcijanina na podstawie wybranych homilii św. Jana Chryzostoma

Święty Jan Chryzostom, który urodził się ok. 349 roku po Chrystusie, był jednym z najwybitniejszych kaznodziejów w historii Kościoła. W swoich homiliach koncentrował się na formacji moralnej chrześcijan. Uczynił to kosztem przepowiadania stricte doktrynalnego. Do dzisiaj zachowały się rozprawy Złotoustego z ówczesnymi herezjami, które podważały boskość Ducha Świętego oraz wystąpienia związane z uroczystością Pięćdziesiątnicy i Epifanii. Do jego wypowiedzi na temat Ducha Świętego należy zaliczyć także niektóre homilie katechetyczne oraz mowy przeciw Żydom, judaizantom i Hellenom. Dynamiczna retoryka oraz bezkompromisowość św. Jana Chryzostoma może być dla współczesnego homilety inspiracją w przygotowywaniu przepowiadania o Duchu Świętym.

Słowa kluczowe: św. Jan Chryzostom, Złotousty, homilia, Duch Święty

The Work of the Holy Spirit in the Life of a Christian Based on Selected Homilies of Saint. Jan Chrysostom

St. John Chrysostom, who was born about 349 after Christ, was one of the greatest preachers in the history of the Church. In his homilies, he focused on the moral formation of Christians. He did so at the expense of strictly doctrinal preaching. To this day, only his polemical homilies with heresies of that time have been preserved, which undermined the divinity of the Holy Spirit and the occurrence connected with the celebration of Pentecost and Epiphany. His statements about the Holy Spirit include also some catechetical homilies and speeches against Jews, Judaizers and Hellenes. Dynamic rhetoric and intransigence of Saint John Chrysostom can be an inspiration for the modern homilist in preparing the proclamation of the Holy Spirit.

Keywords: Saint John Chrysostom, Homily, Holy Spirit

\section{Bibliografia}

Chryzostom J., Mowy przeciw judaizantom i Żydom. Przeciwko Żydom i Hellenom, Kraków 2007.

Chryzostom J., Komentarz do Listu do Galatów, Kraków 2008.

Chryzostom J., Katechezy chrzcielne, Lublin 1993.

Kelly J.N.D., Złote usta. Jan Chryzostom, Bydgoszcz 2001.

Migne J. P., Patrologia Graeca, vol. 48, Paryż 1862, col. 735-748. 
Migne J. P., Patrologia Greaca, vol. 49, Paryż 1862, col. 352-362.

Migne J. P., Patrologia Greaca, vol. 49, Paryż 1862, col. 363-372.

Migne J.P., Patrologia Greaca, vol. 50, Paryż 1862, col. 453- 464.

Starowiejski M., Antiocheńskie katechezy chrzcielne w IV wieku, w: J. Chryzostom, Katechezy chrzcielne, Lublin 1993, s. 5-11. 
